\title{
Classification of Building Structures Located in Industrial Plants with Regard to Calculating Property Tax ${ }^{* *}$
}

\section{Introduction}

Classification of assets of industrial plants for tax purposes poses a serious problem which requires the evaluator to have knowledge of the law, of the construction, and of the process engineering of a plant. There are also additional difficulties resulting from imprecise and inconsistent provisions of the legislation, which constitute the basis for the classification. It gives rise to lengthy and costly litigation between taxpayers and administrative authorities.

This article discusses selected criteria of classifying assets of industrial plants for the purpose of calculating property tax, on the basis of the Construction Law [4], with consideration to the Act on Local Taxes and Fees [3]. It also provides examples of classifying building structures located in industrial plants based on the adopted criteria.

\section{Classification Basis and Definitions of Basic Concepts}

The basis for classifying assets of industrial plants is the Construction Law of 7 July 1994 [4]. This Act regulates activities involving the issues related to the design, construction, maintenance and demolition of building structures, as well as defining principles for the operation of the state administration in these fields. In the analyzed case, the provisions contained in the Act on Local Taxes and Fees [3] are also of great importance.

In order to carry out an appropriate classification of building structures, the meaning of the basic terms used in these laws must be clearly defined first.

* AGH University of Science and Technology, Faculty of Mining Surveying and Environmental Engineering, Krakow, Poland

** This article was prepared within the scope of the AGH statutory research no. 11.11.150.005 
Pursuant to article 3 of the Construction Law [4], a building structure is:

- a building with installations and technical equipment,

- a structure which is a technical and utility whole, together with installations and equipment,

- an object of landscape architecture.

Below there are detailed definitions of these concepts, which are set out in article 3 [4]:

- a building - such a building structure that is permanently affixed to land, separated from the space by wall barriers, and has foundations and a roof;

- a structure - any building structure which is not a building or an object of landscape architecture, such as: linear objects, airports, bridges, viaducts, overpasses, tunnels, culverts, technical networks, freestanding masts, freestanding advertising facilities permanently affixed to the ground, earthworks, defense structures (fortifications), protection structures, hydro engineering structures, tanks, freestanding industrial installations or technical equipment, sewage treatment plants, landfills, water treatment plants, retaining structures, pedestrian crossings on ground level and underground ones, public utilities, sports facilities, cemeteries, monuments, and also construction parts of technical equipment (boilers, industrial furnaces, wind turbines, nuclear power plants and other facilities), as well as foundations for machinery and equipment, as technically distinct portions of the objects that make up the utility whole;

- an object of landscape architecture - small objects, in particular:

a) religious, such as chapels, roadside crosses, statues,

b) statues, fountains and other objects of garden architecture,

c) utility for daily recreation and order maintenance, such as sandboxes, swings, ladders, garbage enclosures.

In the analyzed case, the following definitions are also important:

- a linear object - a building structure, whose characteristic parameter is the length, in particular a road with exits, railway, water supply pipeline, canal, gas pipeline, heat pipeline, pipeline, electricity power line and overhead power transmission line, overhead cable line and placed directly in the ground (underground line), dikes and cables in sewage system, where the cables installed in it do not constitute a building structure nor part thereof, nor building's infrastructure;

- building's infrastructure - technical equipment connected with a building structure, providing for a possibility to use the object according to its intended purpose, such as utilities and installation equipment, including those for the treatment or the accumulation of sewage, as well as crossings, fences, parking places and sites under garbage enclosures. 
In the Act on Local Taxes and Fees [2], the concept of a "structure" was defined slightly differently, which is essential from the point of view of calculating property taxes in industrial plants. Pursuant to article 1a [3] a structure is an object, within the meaning of the Construction Law, which is not a building or an object of landscape architecture, as well as a building's infrastructure, under the provisions of the Construction Law, associated with a building structure, which provides for a possibility to use the object as intended.

The discrepancies in the definition of the term "structure" in the Construction Law [4] and the Act on Local Taxes and Fees [3] can be a big hindrance in unambiguous classification for tax purposes.

\section{Classification Criteria for Building Structure Based on the Construction Law}

On the basis of the interpretation of legislation [2-4] and the experience of the authors, general classification criteria for the assets of industrial plants for tax purposes have been specified and presented below. Taking into account the adopted criteria, the authors classified some objects of several industrial plants for calculating property tax [1]. Difficulties which occurred during the classification procedure, were presented on the example of tanks and silos (Figs 1-4), which, although referred to in the definition of a structure, may resemble buildings or are part of industrial installations implementing the production process of the plant.

Below there are four basic categories of objects, which the assets of industrial plants can be classified as follows:

1) Buildings, or cubature objects having foundations, walls and a roof, which are independent building structures, for example: administrative and social buildings, boiler houses, switchrooms, workshops, production halls, warehouses, etc.

2) Structures are independent (freestanding) objects, which are characterized by the fact that they are permanently affixed to land. In an industrial plant, structures include e.g. cooling towers, industrial chimneys, sheds, roads and squares, tanks/silos (Figs 1, 2), as well as construction parts of the technical equipment, foundations and supporting structures for machinery and equipment (e.g. foundations of electrostatic precipitators, overhead cranes, conveyors, fans, electrical switchgear systems and transformers).

3) Building's infrastructure, or equipment connected with a building structure, providing for a possibility to use the object according to its intended purpose. A building's infrastructure is a special type of technical equipment. When classifying technical equipment to be building's infrastructure, it must be assigned to a building structure, which it is connected with. While determining a building structure, which a given technical equipment remains connected with, it must be demonstrated that it provides a possibility to use such a building structure according to its intended purpose. 
4) Industrial installations and technical equipment are assets necessary to ensure a proper course of the production process carried out in the plant. These include, for instance: electrostatic precipitators, overhead cranes, conveyors, fans, switchgear systems, transformers, weighing scales for trains and vehicles, petrol pumps, pipelines, tanks, etc. Industrial installations and technical equipment can be fixed to a special foundation or supporting structures, both on the outside of buildings (Fig. 3) s well as in their interiors (Fig. 4). They can also be fixed to the structures of buildings on their outer side.

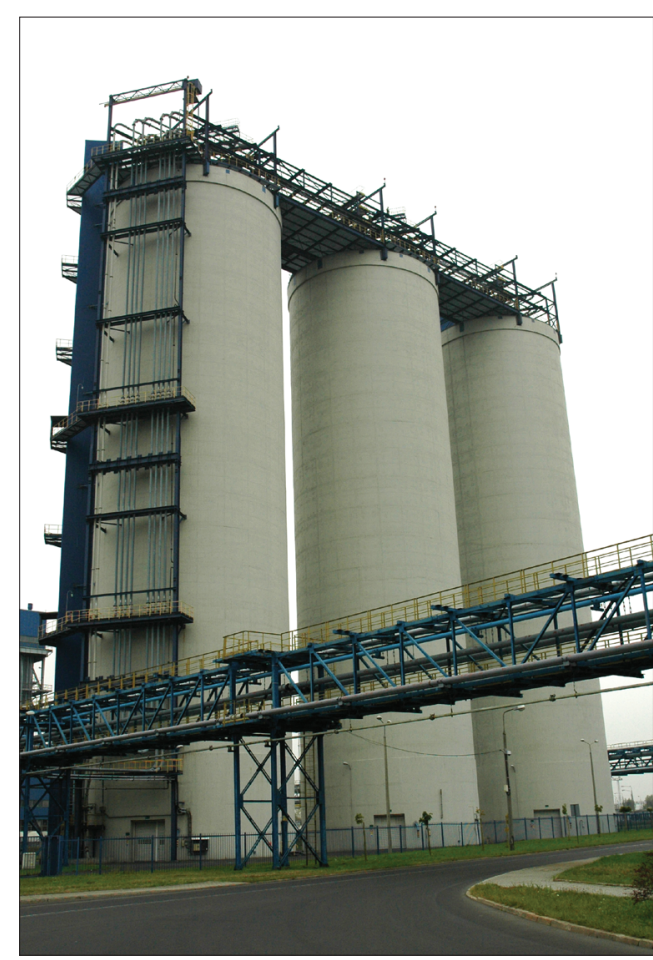

Fig. 1. Fly ash silos in a power plant (structure) Source: [1]

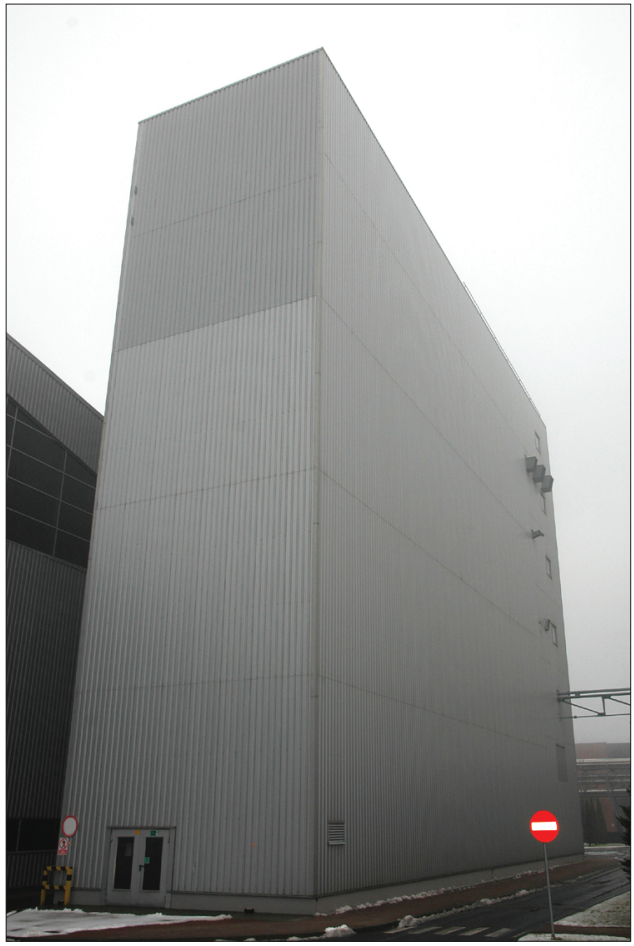

Fig. 2. A group of malt silos in a brewery (structure)

Source: [1]

Installations and equipment mounted on special foundations or supporting structures are not permanently affixed to the land, because they can be disassembled and separated from the foundations or supporting structures. For this reason, industrial installations and technical equipment can not be classified as building structures.

Within the meaning of the Construction Law [4], only buildings and structures of all the items in the above list, can be considered to be building objects. However, according to the Act on Local Taxes and Fees [3], property tax in industrial plants is calculated for buildings, structures and building's infrastructures. 


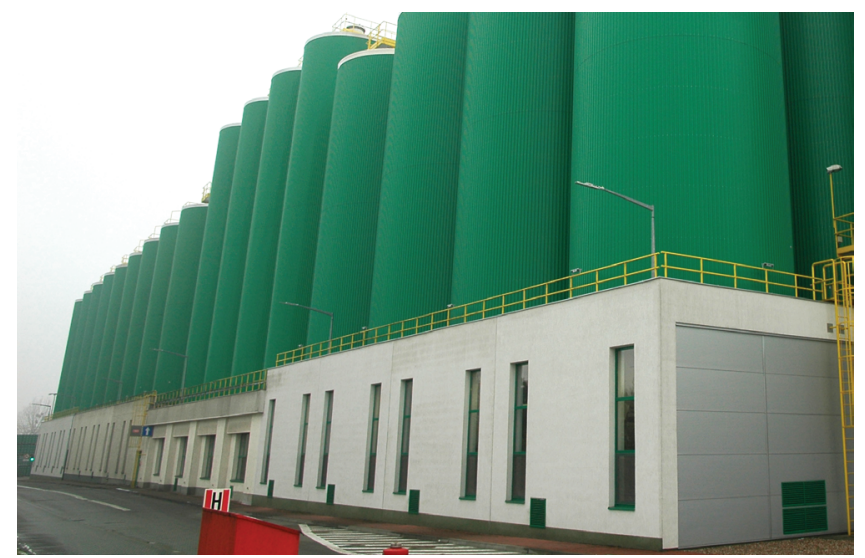

Fig. 3. Fermentation tanks (parts of a process installation) based on a production building in a brewery

Source: [1]

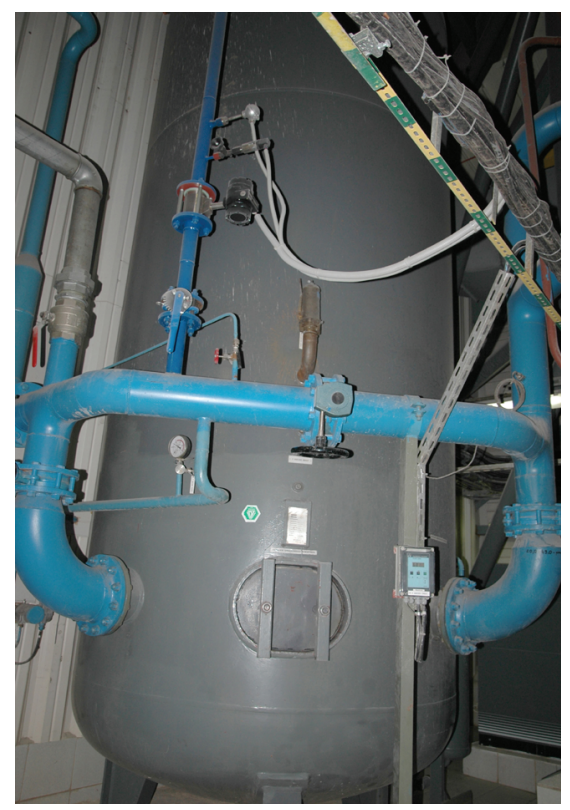

Fig. 4. Compressed air tank (part of a process installation) located in a production building in a power plant

Source: [1]

Due to inconsistent definitions contained in [3, 4], according to the authors, building's infrastructure, industrial installations and technical equipment should be further divided into sub-groups, taking into account their location, the way they are connected with other objects, as well as their technological function. 


\section{Summary}

Industrial plants exhibit a great variety of fixed assets with regard to both structural solutions and their function in the production process. Imprecise nomenclature of these objects, irrelevant to their function, can be frequently noticed as well.

Ambiguous provisions contained in the legislation give rise to differences in interpretation as to the correct classification of objects in terms of calculating property tax between representatives of industrial plants and public administration authorities. This often entail significant discrepancies in the calculation of the tax due on fixed assets, and consequently, leads to lawsuits.

The above mentioned factors result in a necessity for the classification of the assets of industrial plants for calculating property tax to be conducted by specialists in the construction industry, who also have the knowledge of the production process of a given industrial plant, as well as of the Construction Law.

In accordance with the constitutional requirements, unclear tax regulations shall not be interpreted to the detriment of taxpayers.

\section{References}

[1] Opinie techniczne dotyczace kwalifikacji na gruncie ustawy Prawo budowlane wybranych składników majątku zakładów przemystowych. Akademia Górniczo-Hutnicza im. Stanisława Staszica w Krakowie, Wydział Geodezji Górniczej i Inżynierii Środowiska, Katedra Geodezji Inżynieryjnej i Budownictwa, Kraków 2013 [unpublished].

[2] Rozporzadzenie Ministra Infrastruktury z dnia 12 kwietnia 2002 r. w sprawie warunków technicznych, jakim powinny odpowiadać budynki i ich usytuowanie. Dz. U. 2002, nr 75, poz. 690 with amendments.

[3] Ustawa z dnia 12 stycznia 1991 r. o podatkach i opłatach lokalnych. Dz. U. 2002 nr 9, poz. 84 with amendments.

[4] Ustawa z dnia 7 lipca 1994 r. - Prawo budowlane. Dz. U. nr 89, poz. 414 with amendments, unified text: 02.10.2013. Dz. U. 2013, nr 142, poz. 1409. 